\title{
Influence of different organic sources of nutrients on growth and flowering behaviour of pomegranate (Punica granatum L.) cv. Bhagwa
}

\section{Rakesh Kumar Jat ${ }^{*}$}

Department of Fruit Science, College of Horticulture, Sardarkrushinagar Dantiwada Agricultural University, Jagudan, Mehsana-384460 (Gujarat), India

Pankajkumar C. Joshi

Department of Horticulture, C. P. College of Agriculture, Sardarkrushinagar Dantiwada Agricultural University, Sardarkrushinagar, Banaskantha-385506 (Gujarat), India

\section{Piyush Verma}

Department of Horticulture, C. P. College of Agriculture, Sardarkrushinagar Dantiwada Agricultural University, Sardarkrushinagar, Banaskantha-385506 (Gujarat), India

\section{Mohan Lal Jat}

Department of Horticulture, College of Agriculture, Chaudhary Charan Singh Haryana Agricultural University, Hisar-125004 (Haryana), India

\section{Vishal R. Wankhade}

Department of Horticulture, C. P. College of Agriculture, Sardarkrushinagar Dantiwada Agricultural University, Sardarkrushinagar, Banaskantha-385506 (Gujarat), India

*Corresponding author. Email: rkj222@rediffmail.com

\section{How to Cite}

Jat, R. K. et al. (2021). Influence of different organic sources of nutrients on growth and flowering behaviour of pomegranate ( $P$ unica granatum L.) cv. Bhagwa. Journal of Applied and Natural Science, 13(1), 26 - 33. https://doi.org/10.31018/jans.v13i1.2455

\begin{abstract}
A field experiment on the influence of different organic sources of nutrients on growth and flowering behaviour of pomegranate (Punica granatum L.) cv. Bhagwa was conducted at College Farm, College of Horticulture, Sardarkrushinagar Dantiwada Agricultural University, Jagudan, District-Mehsana in Gujarat, India during Mrig bahar (June-January) 2017-18 and 2018-19. The present investigation was laid out in Randomized Block Design with three replications consisting of twenty-two treatments with four different organic manures viz., farmyard manure, vermicompost, poultry manure and neem cake as a source of nitrogen and recommended dose of manure and fertilizers based on plant age with or without biofertilizers (Azotobacter, PSB \& KMB) and biopesticides (Trichoderma viride and Paecilomyces lilacinus). The results based on pooled data revealed that a maximum number of hermaphrodite flowers (85.17) and incomplete flowers (96.50) up to two months after treatment application, fruit set $(69.45 \%)$ along with minimum fruit drop (13.18\%) and days taken for marketable picking (168.83) were significantly (@5\%) noted under treatment $100 \%$ RDN through poultry manure $+50 \mathrm{ml} \mathrm{PSB}+25 \mathrm{ml} \mathrm{KMB}+5 \mathrm{~g}$ Trichoderma viride $+5 \mathrm{ml}$ Paecilomyces lilacinus. However, significantly (@5\%) highest incremental primary growth parameters viz., plant height $(0.60 \mathrm{~m})$, plant spread $(\mathrm{E}-\mathrm{W}: 0.41 \mathrm{~m}$ and N-S: $0.43 \mathrm{~m})$ and stem girth $(1.47 \mathrm{~cm})$ after two months of treatment application were observed under treatment $100 \%$ RDN through vermicompost $+50 \mathrm{ml} \mathrm{PSB}+25 \mathrm{ml} \mathrm{KMB}+5 \mathrm{~g}$ Trichoderma viride $+5 \mathrm{ml}$ Paecilomyces lilacinus. Thus, the organic sources viz., vermicompost and poultry manure with biofertilizers and biopesticides would be very helpful for enhancing vegetative growth and flowering behaviour of the pomegranate.
\end{abstract}

Keywords: Biofertilizers, Biopesticides, Organic manures, Pomegranate, Punica granatum

\section{INTRODUCTION}

The pomegranate (Punica granatum L.) is an important fruit crop of tropical and subtropical regions of the world. It is believed to be originated from Iran. It belongs to the family Punicaceae which has both cultivated (Punica granatum L.) and wild types (Punica pro- topunica Balf) pomegranate. In general, pomegranates are diploids with chromosome number $2 n=2 x=16$. But, some of them are reported to have $2 n=2 x=18$ chromosomes (e.g. Double flowered, an ornamental variety which bears only flowers). $P$. granatum is classified into two sub-species viz., chlorocarpa and porphyrocarpa. Chlorocarpa is found in Transcaucacus 
(Georgia, Armenia, Azerbaijan, Turkey and Iran) regions, while porphyrocarpa is found in Central Asia. Pomegranate has emerged as one of the important fruit crops owing to its high demand for fruits throughout the year besides, hardiness and ability to withstand adverse soil and climate conditions. It is cultivated at a commercial scale in vast regions across the Indian subcontinent, Iran, Caucasus and Mediterranean regions for its fruits. India is one of the leading producers of fruits in the world. Fruit crops are cultivated in India over 6506 thousand ha with a total production of 97358 thousand metric tonnes and productivity of $14.96 \mathrm{t} / \mathrm{ha}$ (Anonymous, 2018). In India, pomegranate is cultivated in 233.93 thousand hectare area with 2844.52 thousand metric tonnes production (Anonymous, 2018). Due to its hardiness, drought tolerance nature, high productivity and profitability to the growers, it is valued for replacing subsistence farming and alleviating poverty and acreage under this fruit crop has increased substantially. However, its intensive cultivation involving indiscriminate use of chemical pesticides along with improper nutrient management is deleterious to the plant health and environment also. Due to these practices, the plants also become susceptible to several biotic and abiotic stresses. Such practices are also common among the pomegranate ( $P$. granatum ) growers.

Considering the health-importance of plant, soil and environment, more rational approach to different organic sources of nutrients should be employed to restore the depleted soil fertility and enhance the available pool of nutrients to the plants, which could benefit the crop in term of vegetative growth. In this background information, the present study, therefore, was focused and planned with the objective to study the effect of organic sources of nutrients and biofertilizers on growth and flowering behaviour of $P$. granatum.

\section{MATERIALS AND METHODS}

The field experiment was conducted during Mrig bahar (June-January) 2017-18 and 2018-19 at the College Farm, College of Horticulture, Sardarkrushinagar Dantiwada Agricultural University, Jagudan, District: Mehsana, Gujarat on two years old uniform plants of pomegranate $\mathrm{cv}$. Bhagwa in size and growth which planted at spacing of $2.5 \mathrm{~m} \times 2.5 \mathrm{~m}$. Jagudan is geographically situated on $23^{\circ} 53^{\prime}$ North and $74^{\circ} 43^{\prime}$ East longitude at an altitude of 90.6 metres above mean sea level. The climate of the study area is semi-arid climate with extreme cold winter and hot with dry windy summer. Generally, monsoon commences in the middle of June and retreats by the middle of September. Most of the precipitation is received from South-West monsoon, concentrating in the months of July and August. The experiment was laid out in randomized block design comprising of 22 treatments with 3 replication having 2 plants per replication. Various treatments were- $T_{1}-$ Recommended dose of FYM and NPK applied through chemical fertilizers (Control), $\mathrm{T}_{2}-\mathrm{T}_{1}+$ Trichoderma viride@ $5 \mathrm{~g}$ and Paecilomyces lilacinus @ $5 \mathrm{ml}$ per plant, $\mathrm{T}_{3}-100 \%$ RDN through FYM, $\mathrm{T}_{4}-100 \%$ RDN through vermicompost, $T_{5}-100 \%$ RDN through poultry manure, $T_{6}-100 \%$ RDN through neem cake, $T_{7}-50$ $\%$ RDN through FYM $+50 \%$ RDN through vermicompost, $\mathrm{T}_{8}-50 \%$ RDN through FYM $+50 \%$ RDN through poultry manure, $\mathrm{T}_{9}-50 \% \mathrm{RDN}$ through FYM + $50 \%$ RDN through neem cake, $\mathrm{T}_{10}-50 \%$ RDN through vermicompost $+50 \%$ RDN through poultry manure, $T_{11}-50 \%$ RDN through vermicompost $+50 \%$ RDN through neem cake, $\mathrm{T}_{12}-50 \%$ RDN through poultry manure $+50 \%$ RDN through neem cake, $\mathrm{T}_{13}-$ $75 \%$ RDN through FYM, $T_{14}-75 \%$ RDN through vermicompost, $\mathrm{T}_{15}-75 \%$ RDN through poultry manure, $\mathrm{T}_{16}-75 \%$ RDN through neem cake, $\mathrm{T}_{17}-37.5 \%$ RDN through $\mathrm{FYM}+37.5 \% \mathrm{RDN}$ through vermicompost, $\mathrm{T}_{18}$ $-37.5 \%$ RDN through FYM + $37.5 \%$ RDN through poultry manure, $\mathrm{T}_{19}-37.5 \% \mathrm{RDN}$ through $\mathrm{FYM}+37.5$ $\%$ RDN through neem cake, $T_{20}-37.5 \%$ RDN through vermicompost $+37.5 \%$ RDN through poultry manure, $\mathrm{T}_{21}-37.5 \%$ RDN through vermicompost $+37.5 \%$ RDN through neem cake and $\mathrm{T}_{22}-37.5 \%$ RDN through poultry manure $+37.5 \%$ RDN through neem cake. Biofertilizers (50 $\mathrm{ml} \mathrm{PSB}$ and $25 \mathrm{ml} \mathrm{KMB}$ ) along with a common dose of Trichoderma viride @ $5 \mathrm{~g}$ and Paecilomyces lilacinus @ $5 \mathrm{ml}$ per plant were applied in the treatments $\mathrm{T}_{3}$ to $\mathrm{T}_{22}$. At the same time, Azotobacter culture @ $50 \mathrm{ml}$ per plant was applied in the treatments $T_{13}$ to $T_{22}$

Application of RDN through different organic manures was also given on the basis of plant age as per treatment which was computed on the inherent availability of nitrogen for the year 2017-18 and 2018-19. The recommended dose of manure and chemical fertilizers were applied in the $T_{1}$ and $T_{2}$ treatments in the present investigation according to the age of pomegranate plant because the recommended dose of manure and chemical fertilizers varies from year to year recommended by National Research Centre on Pomegranate in Table 1 (Sharma et al., 2011). For both these treatments, a full dose of FYM and half dose of $N, P$ and $K$ were applied at desired leaf fall stage on $20^{\text {th }}$ June and rest of $\mathrm{N}, \mathrm{P}$ and $\mathrm{K}$ were applied through chemical fertilizers after 60 days of the first split in each year of the experiment.

The farm yard manure (FYM), vermicompost, poultry manure and neem cake used in present experiment were analyzed for $\mathrm{N}, \mathrm{P}$ and $\mathrm{K}$ content (\%) by using standard methods (Jackson, 1973) before application in the field which is given in Table 2. As per treatment, 50 per cent nitrogen of RDN was applied in the form of FYM, vermicompost, poultry manure and neem cake at desired leaf fall stage on $20^{\text {th }}$ June and remaining dose after 60 days of the first split in each year of the experi- 
Jat, R. K. et al. / J. Appl. \& Nat. Sci. 13(1): 26 - 33 (2021)

Table 1. Recommended manure and chemical fertilizer dose/plant/year for $P$. granatum.

\begin{tabular}{lllll}
\hline Age of plant (Years) & $\begin{array}{l}\text { FYM } \\
(\mathbf{k g})\end{array}$ & $\begin{array}{l}\text { Nitrogen } \\
\mathbf{( g )}\end{array}$ & $\begin{array}{l}\text { Phosphorus } \\
(\mathbf{g})\end{array}$ & $\begin{array}{l}\text { Potash } \\
(\mathbf{g})\end{array}$ \\
\hline 1 & 10 & 250 & 125 & 125 \\
2 & 20 & 250 & 125 & 125 \\
3 & 30 & 500 & 125 & 125 \\
4 & 40 & 500 & 125 & 250 \\
5 and above & 50 & 625 & 250 & 250 \\
\hline
\end{tabular}

Table 2. N, P and K content (\%) of different organic manures for the year 2017-18 and 2018-19 for P. granatum.

\begin{tabular}{llllllll}
\hline \multirow{2}{*}{$\begin{array}{l}\text { Sr. } \\
\text { No. }\end{array}$} & Organic manures & \multicolumn{2}{c}{$\mathbf{N}(\%)$} & \multicolumn{2}{c}{$\mathbf{P}_{\mathbf{2}} \mathbf{O}_{\mathbf{5}}(\%)$} & \multicolumn{2}{c}{$\mathbf{K}_{\mathbf{2}} \mathbf{O}(\%)$} \\
\cline { 3 - 8 } & & $\mathbf{2 0 1 7 - 1 8}$ & $\mathbf{2 0 1 8 - 1 9}$ & $\mathbf{2 0 1 7 - 1 8}$ & $\mathbf{2 0 1 8 - 1 9}$ & $\mathbf{2 0 1 7 - 1 8}$ & $\mathbf{2 0 1 8 - 1 9}$ \\
\hline 1 & FYM & 0.65 & 0.61 & 0.28 & 0.26 & 0.55 & 0.51 \\
2 & Vermicompost & 1.53 & 1.48 & 0.45 & 0.41 & 0.62 & 0.59 \\
3 & Poultry manure & 2.35 & 2.44 & 2.60 & 2.67 & 1.98 & 2.16 \\
4 & Neem cake & 5.22 & 5.15 & 1.12 & 1.08 & 1.50 & 1.47 \\
\hline
\end{tabular}

ment. Application of RDN through different organic sources of nutrients was given on the basis of plant age in the treatment $T_{3}$ to $T_{22}$ as per treatment.

For application of organic manures, a ring having 20 $\mathrm{cm}$ depth with $15 \mathrm{~cm}$ width was made around the plant canopy and manures were uniformly mixed into the ring which was then leveled. The biofertilizers (Azotobacter culture, phosphate solubilizing bacteria and potash mobilizing bacteria) and biopesticides (Trichoderma viride and Paecilomyces lilacinus) were procured from the Laboratory of Department of Plant Pathology, Navsari Agricultural University, Navsari, Gujarat, India and mixed thoroughly with different organic manures as per treatment before its application. The full dose of biofertilizers and biopesticides were applied at the desired leaf fall stage on $20^{\text {th }}$ June in each year of the experiment as per treatment. The plants were moderately pruned during the first fortnight of June in each year of the experimentation period. Other cultural practices, such as weeding and plant protection, were done as and when required. Irrigation was applied immediately after the treatment application. Plants were irrigated daily with drip irrigation system as per water requirement except for rainy season. Primary growth in terms of plant height, plant spread (E-W and N-S) and stem girth were measured before and after two months of treatment application. Further, incremental primary plant height, plant spread (E-W and N-S) and stem girth were calculated. The flowering behaviour data were recorded in terms of days taken for the commencement of flowers after treatment application, a number of hermaphrodite flowers and incomplete flowers (male and intermediate flowers) up to two months after treatment application as well as the ratio of hermaphrodite and incomplete flowers. Fruit set, fruit drop and days taken for marketable picking were also calcu- lated. The experiment was conducted in randomized block design with each treatment replicated thrice. The statistical analysis of the data was carried out as per the method described by Cochran and Cox (1963). The treatment effects were tested at 5 per cent level of significance.

\section{RESULTS AND DISCUSSION}

\section{Incremental primary growth parameters}

The data presented in Table 3 showed non significant differences on plant height, plant spread (E-W and $N$ S) and stem girth before treatment application which indicates homogeneity of these growth parameters in the experimental plot. Incremental primary plant height, plant spread (E-W and N-S) and stem girth obtained after two months of treatment application as influenced by different organic sources of nutrients are presented in Table 4. It is explicit from the data presented in Table 4 that application of $100 \%$ RDN through vermicompost $+50 \mathrm{ml} \mathrm{PSB}+25 \mathrm{ml} \mathrm{KMB}+5 \mathrm{~g}$ Trichoderma viride $+5 \mathrm{ml}$ Paecilomyces lilacinus treatment showed significant (@5\%) maximum incremental primary plant height $(0.60 \mathrm{~m})$ and plant spread (E-W: $0.41 \mathrm{~m} \& \mathrm{~N}-\mathrm{S}$ : $0.43 \mathrm{~m})$. Whereas, minimum incremental primary plant height $(0.30 \mathrm{~m})$ after two months of treatment application was recorded under $100 \%$ RDN through FYM + $50 \mathrm{ml} \mathrm{PSB}+25 \mathrm{ml} \mathrm{KMB}+5 \mathrm{~g}$ Trichoderma viride +5 $\mathrm{ml}$ Paecilomyces lilacinus. Minimum incremental primary plant spread (E-W : $0.14 \mathrm{~m}$ and $\mathrm{N}-\mathrm{S}$ : $0.15 \mathrm{~m}$ ) after two months of treatment application was recorded under treatment $75 \%$ RDN through FYM $+50 \mathrm{ml}$ Azotobacter culture $+50 \mathrm{ml} \mathrm{PSB}+25 \mathrm{ml} \mathrm{KMB}+5 \mathrm{~g}$ Trichoderma viride $+5 \mathrm{ml}$ Paecilomyces lilacinus. The increase in plant height and plant spread (E-W and N-S) might be due to the fact that the application of ver- 
Jat, R. K. et al. / J. Appl. \& Nat. Sci. 13(1): 26 - 33 (2021)

Table 3. Plant growth parameters of Punica granatum before \& after treatment application (2 years pooled data).

\begin{tabular}{|c|c|c|c|c|c|c|c|c|}
\hline \multirow{3}{*}{$\begin{array}{l}\text { Treat- } \\
\text { ment }\end{array}$} & \multirow{2}{*}{\multicolumn{2}{|c|}{ Plant height (m) }} & \multicolumn{4}{|c|}{ Plant spread } & \multirow{2}{*}{\multicolumn{2}{|c|}{ Stem girth $(\mathrm{cm})$}} \\
\hline & & & \multicolumn{2}{|c|}{ East-West (m) } & \multicolumn{2}{|c|}{ North-South (m) } & & \\
\hline & Initial & $\begin{array}{l}\text { After two } \\
\text { months }\end{array}$ & Initial & $\begin{array}{l}\text { After two } \\
\text { months }\end{array}$ & Initial & $\begin{array}{l}\text { After two } \\
\text { months }\end{array}$ & Initial & $\begin{array}{l}\text { After two } \\
\text { months }\end{array}$ \\
\hline$\overline{T_{1}}$ & 1.68 & 2.03 & 1.53 & 1.72 & 1.50 & 1.68 & 17.06 & 18.03 \\
\hline $\mathrm{T}_{2}$ & 1.70 & 2.06 & 1.55 & 1.73 & 1.50 & 1.70 & 17.13 & 18.07 \\
\hline $\mathrm{T}_{3}$ & 1.67 & 1.96 & 1.55 & 1.70 & 1.51 & 1.68 & 17.01 & 17.92 \\
\hline $\mathrm{T}_{4}$ & 1.77 & 2.36 & 1.66 & 2.07 & 1.60 & 2.03 & 19.36 & 20.83 \\
\hline $\mathrm{T}_{5}$ & 1.75 & 2.26 & 1.64 & 2.00 & 1.59 & 1.93 & 18.12 & 19.43 \\
\hline $\mathrm{T}_{6}$ & 1.78 & 2.22 & 1.65 & 1.98 & 1.59 & 1.91 & 18.71 & 20.07 \\
\hline $\mathrm{T}_{7}$ & 1.72 & 2.12 & 1.62 & 1.90 & 1.57 & 1.85 & 17.40 & 18.38 \\
\hline $\mathrm{T}_{8}$ & 1.76 & 2.19 & 1.63 & 1.92 & 1.58 & 1.89 & 17.25 & 18.15 \\
\hline $\mathrm{T}_{9}$ & 1.73 & 2.16 & 1.61 & 1.90 & 1.56 & 1.84 & 17.25 & 18.21 \\
\hline $\mathrm{T}_{10}$ & 1.73 & 2.17 & 1.62 & 1.92 & 1.57 & 1.86 & 17.74 & 18.83 \\
\hline $\mathrm{T}_{11}$ & 1.75 & 2.16 & 1.61 & 1.90 & 1.56 & 1.84 & 17.45 & 18.42 \\
\hline $\mathrm{T}_{12}$ & 1.73 & 2.14 & 1.62 & 1.91 & 1.57 & 1.85 & 17.73 & 18.85 \\
\hline $\mathrm{T}_{13}$ & 1.66 & 1.98 & 1.53 & 1.67 & 1.50 & 1.65 & 17.17 & 18.14 \\
\hline $\mathrm{T}_{14}$ & 1.69 & 2.06 & 1.57 & 1.77 & 1.52 & 1.72 & 17.69 & 18.77 \\
\hline $\mathrm{T}_{15}$ & 1.71 & 2.09 & 1.56 & 1.77 & 1.51 & 1.73 & 17.52 & 18.57 \\
\hline $\mathrm{T}_{16}$ & 1.72 & 2.11 & 1.57 & 1.77 & 1.52 & 1.72 & 17.53 & 18.57 \\
\hline $\mathrm{T}_{17}$ & 1.74 & 2.16 & 1.61 & 1.88 & 1.56 & 1.83 & 17.59 & 18.49 \\
\hline $\mathrm{T}_{18}$ & 1.72 & 2.14 & 1.60 & 1.84 & 1.54 & 1.79 & 17.66 & 18.58 \\
\hline $\mathrm{T}_{19}$ & 1.74 & 2.17 & 1.63 & 1.91 & 1.56 & 1.85 & 17.50 & 18.62 \\
\hline $\mathrm{T}_{20}$ & 1.71 & 2.09 & 1.59 & 1.83 & 1.54 & 1.78 & 18.16 & 19.34 \\
\hline $\mathrm{T}_{21}$ & 1.73 & 2.16 & 1.60 & 1.87 & 1.54 & 1.81 & 18.23 & 19.48 \\
\hline $\mathrm{T}_{22}$ & 1.71 & 2.09 & 1.60 & 1.84 & 1.54 & 1.79 & 17.20 & 18.17 \\
\hline S.Em. \pm & 0.04 & 0.04 & 0.05 & 0.05 & 0.05 & 0.04 & 0.45 & 0.44 \\
\hline $\begin{array}{l}\text { C.D. at } \\
5 \%\end{array}$ & NS & 0.12 & NS & 0.14 & NS & 0.12 & NS & 1.23 \\
\hline C.V. \% & 6.03 & 5.22 & 8.21 & 7.03 & 8.65 & 6.65 & 6.87 & 6.26 \\
\hline
\end{tabular}

micompost along with PSB leads to phosphorus mobilization from soil pool to plant system and increased nitrogen availability due to proper nitrogen fertilization and fixation. These are in accordance with the findings of Chandra et al. (2016) by the application of $75 \%$ recommended dose of fertilizers (RDF) + cowdung slurry @ 10 litre per tree + Azospiillum $100 \mathrm{~g}$ per tree + PSB $100 \mathrm{~g}$ per tree in guava and Sourabh et al. (2018) recorded highest plant height under the treatment Azotobacter + PSB inoculation along with 100\% RDF + Vermicompost in guava. Growth regulators like auxins, gibberellins and cytokinins were released more in root zone due to increased microbial inoculants with the addition of vermicompost in pomegranate (Mir et al., 2015). Similar results were also reported by Naik and Babu (2007) in guava with the application of $10 \mathrm{~kg}$ vermicompost per tree and Kurer et al. (2017) in pomegranate by $100 \%$ RDN through vermicompost. Choudhary (2016) reported that vermicompost altered various enzymatic activities in plants such as peroxidase, catalase etc., which promote cell elongation, root and shoot growth and carbohydrate metabolism in ber
(Zizyphus mauritiana Lam.). In the present study, significantly (@5\%) maximum incremental primary stem girth $(1.47 \mathrm{~cm})$ after two months of treatment application was recorded under treatment $100 \%$ RDN through vermicompost $+50 \mathrm{ml} \mathrm{PSB}+25 \mathrm{ml} \mathrm{KMB}+5 \mathrm{~g}$ Trichoderma viride $+5 \mathrm{ml}$ Paecilomyces lilacinus. The treatment $\mathrm{T}_{4}$ was statistically at par with $\mathrm{T}_{6}$ treatment. Minimum incremental primary stem girth $(0.90 \mathrm{~cm})$ after two months of treatment application was noted in treatment $37.5 \%$ RDN through FYM + $37.5 \%$ RDN through vermicompost $+50 \mathrm{ml}$ Azotobacter culture $+50 \mathrm{ml} \mathrm{PSB}+$ $25 \mathrm{ml} \mathrm{KMB}+5 \mathrm{~g}$ Trichoderma viride $+5 \mathrm{ml}$ Paecilomyces lilacinus. The increase in stem girth $(\mathrm{cm})$ might be due to synergistic effect of vermicompost and PSB at higher dose augmented by enhanced availability of macro and micro nutrients, growth hormones (auxin and gibberellins), vitamins, enzymes, humic acid and beneficial microbes to the crop plants (Anitha et al., 2003) and mineralization may account for the higher nitrogen content which led to the increase in soil fertility status, ultimately facilitating higher uptake of nutrient and improving plant growth (Atiyeh et al., 2002). The 
Table 4. Influence of different organic sources of nutrients on incremental primary growth parameters $(\mathrm{m})$ of Punica granatum after two months of treatment application (2 years pooled data).

\begin{tabular}{|c|c|c|c|c|}
\hline \multirow{2}{*}{ Treatment } & \multirow{2}{*}{ Plant height $(\mathrm{m})$} & \multicolumn{2}{|c|}{ Plant spread } & \multirow{2}{*}{ Stem girth (cm) } \\
\hline & & East-West (m) & North-South (m) & \\
\hline $\mathrm{T}_{1}$ & 0.36 & 0.19 & 0.18 & 0.97 \\
\hline $\mathrm{T}_{2}$ & 0.37 & 0.18 & 0.20 & 0.94 \\
\hline$T_{3}$ & 0.30 & 0.15 & 0.17 & 0.91 \\
\hline $\mathrm{T}_{4}$ & 0.60 & 0.41 & 0.43 & 1.47 \\
\hline$T_{5}$ & 0.51 & 0.36 & 0.34 & 1.30 \\
\hline$T_{6}$ & 0.44 & 0.33 & 0.32 & 1.35 \\
\hline $\mathrm{T}_{7}$ & 0.40 & 0.28 & 0.28 & 0.98 \\
\hline $\mathrm{T}_{8}$ & 0.43 & 0.29 & 0.31 & 0.91 \\
\hline $\mathrm{T}_{9}$ & 0.43 & 0.28 & 0.28 & 0.96 \\
\hline$T_{10}$ & 0.44 & 0.30 & 0.30 & 1.09 \\
\hline $\mathrm{T}_{11}$ & 0.41 & 0.28 & 0.28 & 0.97 \\
\hline $\mathrm{T}_{12}$ & 0.41 & 0.29 & 0.28 & 1.12 \\
\hline$T_{13}$ & 0.31 & 0.14 & 0.15 & 0.96 \\
\hline $\mathrm{T}_{14}$ & 0.37 & 0.20 & 0.21 & 1.08 \\
\hline$T_{15}$ & 0.39 & 0.21 & 0.22 & 1.04 \\
\hline $\mathrm{T}_{16}$ & 0.40 & 0.21 & 0.21 & 1.04 \\
\hline$T_{17}$ & 0.42 & 0.27 & 0.27 & 0.90 \\
\hline $\mathrm{T}_{18}$ & 0.41 & 0.25 & 0.25 & 0.92 \\
\hline $\mathrm{T}_{19}$ & 0.42 & 0.29 & 0.29 & 1.12 \\
\hline $\mathrm{T}_{20}$ & 0.39 & 0.24 & 0.24 & 1.17 \\
\hline $\mathrm{T}_{21}$ & 0.42 & 0.26 & 0.27 & 1.25 \\
\hline $\mathrm{T}_{22}$ & 0.38 & 0.24 & 0.24 & 0.98 \\
\hline S.Em. \pm & 0.01 & 0.01 & 0.01 & 0.05 \\
\hline C.D. at $5 \%$ & 0.04 & 0.03 & 0.03 & 0.13 \\
\hline C.V. \% & 8.37 & 10.47 & 11.61 & 11.46 \\
\hline
\end{tabular}

study was also supported by findings of Arancon et al. (2004) in strawberry and Sharma et al. (2016) in custard apple.

\section{Flowering behaviour}

It is clear from the data presented in Table 5 that the application of different organic sources of nutrients did not have any significant influence on days taken for the commencement of flowers after treatment application and ratio of hermaphrodite and incomplete flowers up to two months after treatment application. The data pertaining to number of hermaphrodite flowers and incomplete flowers up to two months after treatment application as influenced by different organic sources of nutrients are presented in Table 5. Significantly maximum number of hermaphrodite flowers (85.17) and incomplete flowers (96.50) were recorded with $100 \%$ RDN through poultry manure $+50 \mathrm{ml} \mathrm{PSB}+25 \mathrm{ml} \mathrm{KMB}$ $+5 \mathrm{~g}$ Trichoderma viride $+5 \mathrm{ml}$ Paecilomyces lilacinus treatment up to two months after treatment application. The treatment $T_{5}$ was at par with $T_{6}$ treatment for a number of incomplete flowers up to two months after treatment application. Whereas, the minimum number of hermaphrodite flowers (66.67) and incomplete flowers (78.67) were recorded with treatment $75 \%$ RDN through FYM $+50 \mathrm{ml}$ Azotobacter culture $+50 \mathrm{ml} \mathrm{PSB}$ $+25 \mathrm{ml} \mathrm{KMB}+5 \mathrm{~g}$ Trichoderma viride $+5 \mathrm{ml}$ Paecilomyces lilacinus up to two months after treatment application. The highest number of hermaphrodite and incomplete flowers in pomegranate might be due to the maximum availability of phosphorus supplied from poultry manure along with PSB which involves in stimulating, enhancing bud development and blooming of more flowers. These could be attributed to the capability of soil microorganisms to produce growth regulators such as auxins, cytokinins and gibberellins which had a positive influence on the flowering process and nutrients uptake which was also recorded by Hassan et al. (2015) in olive. These results are in accordance with the findings of Kurer et al. (2017) and Marathe et al. (2017) through the application of poultry manure in pomegranate. The high endogenous ratio of carbohydrate to nitrogen ( $\mathrm{C}: \mathrm{N}$ ratio) promotes flowering whereas, high nitrogen availability resulting low $\mathrm{C}: \mathrm{N}$ 
Table 5. Influence of different organic sources of nutrients on flowering behaviour of $P$. granatum (2 years pooled data).

\begin{tabular}{|c|c|c|c|c|c|c|c|}
\hline Treatment & $\begin{array}{l}\text { Days taken for } \\
\text { commence- } \\
\text { ment of flowers } \\
\text { after treatment } \\
\text { application }\end{array}$ & $\begin{array}{l}\text { Number of } \\
\text { hermaphrodite } \\
\text { flowers up to } \\
\text { two months } \\
\text { after treatment } \\
\text { application }\end{array}$ & $\begin{array}{l}\text { Number of } \\
\text { incomplete } \\
\text { flowers up to } \\
\text { two months } \\
\text { after treatment } \\
\text { application }\end{array}$ & $\begin{array}{l}\text { Ratio of } \\
\text { her- } \\
\text { maphro } \\
\text { dite \& } \\
\text { incom- } \\
\text { plete } \\
\text { flowers }\end{array}$ & $\begin{array}{l}\text { Fruit } \\
\text { set } \\
(\%)\end{array}$ & $\begin{array}{l}\text { Fruit } \\
\text { drop } \\
(\%)\end{array}$ & $\begin{array}{l}\text { Days tak- } \\
\text { en for } \\
\text { marketa- } \\
\text { ble pick- } \\
\text { ing }\end{array}$ \\
\hline $\mathrm{T}_{1}$ & 31.50 & 71.67 & 87.00 & 0.82 & 63.53 & 16.19 & 173.83 \\
\hline $\mathrm{T}_{2}$ & 31.50 & 73.33 & 87.67 & 0.84 & 65.43 & 16.14 & 173.17 \\
\hline $\mathrm{T}_{3}$ & 30.83 & 69.67 & 83.50 & 0.83 & 59.86 & 16.35 & 175.33 \\
\hline $\mathrm{T}_{4}$ & 30.50 & 77.33 & 90.67 & 0.85 & 66.45 & 15.22 & 174.83 \\
\hline $\mathrm{T}_{5}$ & 29.83 & 85.17 & 96.50 & 0.88 & 69.45 & 13.18 & 168.83 \\
\hline $\mathrm{T}_{6}$ & 30.17 & 79.17 & 92.33 & 0.85 & 67.88 & 14.42 & 170.33 \\
\hline $\mathrm{T}_{7}$ & 31.17 & 72.50 & 86.67 & 0.84 & 60.31 & 19.22 & 175.50 \\
\hline $\mathrm{T}_{8}$ & 31.17 & 73.33 & 87.67 & 0.84 & 61.90 & 17.02 & 173.00 \\
\hline $\mathrm{T}_{9}$ & 31.50 & 76.67 & 90.50 & 0.85 & 65.69 & 16.08 & 172.33 \\
\hline $\mathrm{T}_{10}$ & 31.33 & 78.00 & 91.17 & 0.85 & 66.76 & 15.02 & 173.33 \\
\hline $\mathrm{T}_{11}$ & 30.83 & 74.00 & 88.50 & 0.84 & 65.33 & 14.60 & 173.50 \\
\hline $\mathrm{T}_{12}$ & 31.00 & 77.67 & 91.17 & 0.85 & 66.87 & 15.62 & 173.00 \\
\hline $\mathrm{T}_{13}$ & 32.17 & 66.67 & 78.67 & 0.85 & 57.34 & 17.73 & 175.50 \\
\hline $\mathrm{T}_{14}$ & 31.67 & 72.67 & 87.67 & 0.83 & 62.06 & 16.43 & 175.83 \\
\hline $\mathrm{T}_{15}$ & 32.00 & 73.17 & 86.83 & 0.84 & 62.99 & 15.32 & 175.50 \\
\hline $\mathrm{T}_{16}$ & 31.17 & 71.00 & 85.67 & 0.83 & 62.32 & 16.09 & 175.50 \\
\hline $\mathrm{T}_{17}$ & 31.33 & 69.17 & 83.50 & 0.83 & 60.74 & 17.56 & 175.83 \\
\hline $\mathrm{T}_{18}$ & 31.17 & 67.50 & 81.00 & 0.83 & 62.37 & 16.83 & 174.83 \\
\hline $\mathrm{T}_{19}$ & 30.83 & 76.50 & 90.17 & 0.85 & 65.27 & 15.71 & 172.83 \\
\hline $\mathrm{T}_{20}$ & 32.00 & 69.83 & 84.17 & 0.83 & 63.53 & 16.08 & 175.17 \\
\hline $\mathrm{T}_{21}$ & 30.67 & 73.33 & 87.00 & 0.84 & 65.72 & 14.78 & 173.00 \\
\hline $\mathrm{T}_{22}$ & 31.17 & 70.17 & 83.83 & 0.84 & 62.47 & 16.14 & 175.17 \\
\hline S.Em. \pm & 0.56 & 2.08 & 1.80 & 0.01 & 1.34 & 0.58 & 1.28 \\
\hline C.D. at 5\% & NS & 5.83 & 5.05 & NS & 3.75 & 1.62 & 3.57 \\
\hline C.V. \% & 4.88 & 7.51 & 5.48 & 4.61 & 5.70 & 9.76 & 2.00 \\
\hline
\end{tabular}

ratio promotes vegetative growth (Bernier et al., 1981 and Rideout et al., 1992). These results are also in accordance with the findings of Thanari and Suma (2018) under treatment $25 \%$ SA + $75 \%$ F (Schedule-2) and with application of $50 \% \mathrm{RDN}$ and $\mathrm{P}_{2} \mathrm{O}_{5}(200: 100: 200$ $\mathrm{N}: \mathrm{P}_{2} \mathrm{O}_{5}: \mathrm{K}_{2} \mathrm{O}$ gram per plant) $+20 \mathrm{~kg}$ oil cakes + bioinoculants treatment by Greeshma et al. (2017) in pomegranate. Fruit set (\%), fruit drop (\%) and days taken for marketable picking as influenced by different organic sources of nutrients are presented in Table 5. Application of $100 \%$ RDN through poultry manure $+50 \mathrm{ml}$ $\mathrm{PSB}+25 \mathrm{ml} \mathrm{KMB}+5 \mathrm{~g}$ Trichoderma viride $+5 \mathrm{ml}$ Paecilomyces lilacinus treatment noted significantly maximum fruit set $(69.45 \%)$ which was followed by $T_{6}, T_{12}$, $\mathrm{T}_{10}, \mathrm{~T}_{4}$ and $\mathrm{T}_{21}$ treatments. Whereas, minimum fruit set was recorded in $75 \%$ RDN through FYM + $50 \mathrm{ml}$ Azo- tobacter culture $+50 \mathrm{ml} \mathrm{PSB}+25 \mathrm{ml} \mathrm{KMB}+5 \mathrm{~g}$ Trichoderma viride $+5 \mathrm{ml}$ Paecilomyces lilacinus treatment with the value of $57.34 \%$. The higher fruit set in pomegranate could be associated with the availability of phosphorus nutrient for plants supplied through poultry manure and PSB biofertilizer, which plays an essential role in fruit setting. The phosphorus element is involved in stimulating and enhancing bud development, blooming and fruit set. These results are in accordance with findings of Baviskar et al. (2011) in sapota by the application of 1125:750:375 g NPK + $15 \mathrm{~kg}$ vermicompost + $250 \mathrm{~g}$ Azotobacter $+250 \mathrm{~g} \mathrm{PSB} /$ plant) and, with the application of poultry manure by Kurer et al. (2017) and with use of $50 \%$ compost $+50 \%$ poultry manure + natural rocks + biofertilizers by Mohamed et al. (2018) in pomegranate. Significantly minimum fruit drop (13.18 
$\%)$ was recorded under treatment $100 \%$ RDN through poultry manure $+50 \mathrm{ml} \mathrm{PSB}+25 \mathrm{ml} \mathrm{KMB}+5 \mathrm{~g}$ Trichoderma viride $+5 \mathrm{ml}$ Paecilomyces lilacinus which was statistically at par $T_{6}, T_{11}$ and $T_{21}$ treatments. Whereas, maximum fruit drop was recorded under treatment 50 $\%$ RDN through $\mathrm{FYM}+50 \% \mathrm{RDN}$ through vermicompost $+50 \mathrm{ml} \mathrm{PSB}+25 \mathrm{ml} \mathrm{KMB}+5 \mathrm{~g}$ Trichoderma viride $+5 \mathrm{ml}$ Paecilomyces lilacinus with the value of $19.22 \%$. Minimum fruit drop might be due to more availability of micronutrients during the growth period, more fruit retention and adequate hormonal balance. These results are in line with the findings of Sharma (2015) in mango with the application of vermicompost (25 kg per plant) + oil cake $(2.5 \mathrm{~kg}$ per plant $)+$ Azotobacter + VAM + Trichoderma viride (100 g per plant each), with the usage of RDF + Sujala @ 5 ppm + Microla @ 2 ppm (5 sprays) by Gawade et al. (2018) in pomegranate and with the application of combined treatment of granule humic and biofertilizer by Torshiz et al. (2017) in pomegranate. Statistically, minimum days (168.83) taken for marketable picking was recorded under treatment $100 \%$ RDN through poultry manure $+50 \mathrm{ml} \mathrm{PSB}+25 \mathrm{ml} \mathrm{KMB}+5 \mathrm{~g}$ Trichoderma viride +5 $\mathrm{ml}$ Paecilomyces lilacinus followed by $\mathrm{T}_{6}$ and $\mathrm{T}_{9}$ treatments. Whereas, maximum days (175.83) taken for marketable picking was recorded under $T_{14}$ and $T_{17}$ treatments. Minimum days taken for marketable picking in pomegranate plants might be due to the fact that the application of poultry manure along with biofertilizers and biopesticides improved availability of phosphorus element and its absorption due to better root growth and development resulted in early picking of pomegranate fruits at the marketable stage. The result is in accordance with the findings of Adhikari et al. (2016) in sweet pepper with the application of poultry manure, and vermicompost and with that of Rehman et al. (2015) who noted that brinjal plants are grown under the organic regime (FYM @ 25 t/ha, poultry manure @ 5 t/ha and mushroom waste @ 10 t/ha) took the least days to harvest as compared to plants grown under the inorganic regime.

\section{Conclusion}

On the basis of pooled data, it could be concluded that the application of $100 \%$ RDN through vermicompost + $50 \mathrm{ml} \mathrm{PSB}+25 \mathrm{ml} \mathrm{KMB}+5 \mathrm{~g}$ Trichoderma viride +5 $\mathrm{ml}$ Paecilomyces lilacinus was found significantly (@5\%) better to get maximum growth parameters, i.e. incremental plant height, plant spread (E-W \& N-S) and stem girth of Punica granatum. While a maximum number of hermaphrodite flowers and incomplete flowers up to two months after treatment application as well as fruit set along with minimum fruit drop and days taken for marketable picking were significantly (@5\%) recorded through the application of $100 \%$ RDN through poultry manure $+50 \mathrm{ml} \mathrm{PSB}+25 \mathrm{ml} \mathrm{KMB}+5 \mathrm{~g}$ Trichoderma viride $+5 \mathrm{ml}$ Paecilomyces lilacinus in pomegranate cv. Bhagwa. Thus, the organic sources viz., vermicompost and poultry manure with biofertilizers and biopesticides were found very effective for enhancing vegetative growth and flowering behaviour of the pomegranate.

\section{Conflict of interest}

The authors declare that they have no conflict of interest.

\section{REFERENCES}

1. Adhikari, P., Khanal, A. \& Subedi, R. (2016). Effect of different sources of organic manure on growth \& yield of sweet pepper. Advances in Plants \& Agriculture Research, 3(5), 158-161.

2. Anitha, S., Joyithi, M. L. \& Narayanan Kutti, M. C. (2003). Evaluation of various organic manures as components in the integrated nutrient management of oriental pickling melon. Progressive Horticulture, 35, 155-157.

3. Anonymous (2018). Horticultural Statistics at a Glance, Horticulture Statistics Division, Department of Agriculture, Cooperation \& Farmers Welfare, Ministry of Agriculture \& Farmers' Welfare, Government of India, New Delhi. p. 458.

4. Arancon, N. Q., Edwards, C. A., Bierman, P., Welch, C. \& Metzger, J. D. (2004). Influence of vermicompost on field strawberry on growth \& yield. Bioresource Technology, 93 (2), 145-153.

5. Atiyeh, R. M., Lee, S., Edwards, C. A., Arancon, N. Q. \& Metzger, J. D. (2002). The influence of humic acids derived from earthworm-processed organic wastes on plant growth. Bioresource Technology, 84(1), 7-14.

6. Baviskar, M. N., Bharad, S. G., Dod, V. N. \& Barne, V. G. (2011). Effect of integrated nutrient management on yield \& quality of sapota. Plant Archives, 11(2), 661-663.

7. Bernier, G., Kinet, J. M. \& Sachs, R. M. (1981). The Physiology of Flowering. Vol I, CRC Press, Boca Raton. p.159.

8. Chandra, V., Sharma, H. G. \& Dikshit, S. N. (2016). Effect of chemical fertilizers, organic manures \& biofertilizers on growth, yield \& quality of mrig bahar guava (Psidium guajava L.). Current Advances in Agricultural Sciences, 8 (1), 114-116.

9. Choudhary, R. (2016). Effect of organic manures \& fertility levels on growth parameters of ber (Zizyphus mauritiana Lam.) cv. Gola under semi-arid conditions. In: M.Sc. (Agri.) Thesis, Sri Karan Narendra Agriculture University, Jobner.

10. Cochran, G. C. \& Cox, G. M. (1963). Experimental Design. Asia Publishing House, Bombay. p.611.

11. Gawade, S. N., Kale, A. P., Shaikh, J. A. \& Sharma, R. C. (2018). Study on nutrient package for pomegranate (Punica granatum L.). Indian Journal of Agricultural Research, 52(2), 199-202.

12. Greeshma, R. B. C., Suma, R., Nagaraja, M. S. \& Kulapati, H. (2017). Effect of bioinoculants \& organic supplementation on growth \& yield of pomegranate. International Journal of Environmental Sciences \& Natural Resources, $4(4), 1-5$. 
13. Hassan, A. M., Abd-Alhamid, N., Rawheya, B. M. A. A. Hassan, H. S. A., Abdelhafez, A. A. \& Laila, F. H. (2015). Effect of organic \& biofertilization on yield \& quality of "Manzanillo" olives. Middle East Journal of Agriculture Research, 4(3), 485-493.

14. Jackson, M. L. (1973). Soil Chemical Analysis. PrenticeHall of India Private Limited, New Delhi. p 498.

15. Kurer, B. S., Patil, D. R., Gandolkar , K., Mesta, R. K., Nagaraj, M. S., Nadaf, A. M. \& Prakash, D. P. (2017). Response of pomegranate to different organic manures under northern dry zone of Karnataka, India. International Journal of Current Microbiology \& Applied Sciences, 6 (11), 86-90.

16. Marathe, R. A., Sharma, J., Murkute, A. A. \& Babu, K. D. (2017). Response of nutrient supplementation through organics on growth, yield \& quality of pomegranate. Scientia Horticulturae, 214, 114-121.

17. Mir, M., Sharma, S. D. \& Kumar, P. (2015). Nutrient dynamics: Effect on cropping behavior, nutrient profile \& quality attributes of pomegranate (Punica granatum L.) under rainfed agro-climatic conditions. Journal of Plant Nutrition, 38(1), 83-95.

18. Mohamed, A. S., Shohba, N. E. A., Abou-Taleb, S. A., Abbas, M. S. \& Soliman, A. S. (2018). Beneficial effect of bioorganic fertilizers as a partial replacement of chemical fertilizers on productivity \& fruit quality of pomegranate trees. Bioscience Research, 15(4), 4603-4616.

19. Naik, M. H. \& Babu, R. S. H. (2007). Feasibility of organic farming in guava. Acta Horticulturae, 735, 365-372.

20. Rehman, A., Shahid, M., Malik, A. A., Khan, S. \& Zakaria (2015). Effect of organic \& inorganic fertilizers on brinjal cultivars under the agro-climatic conditions of Mansehra. Journal of Biology, Agriculture \& Healthcare, 5(11), 14-19.
21. Rideout, J. W., Raper, C. D. \& Miner, G. S. (1992). Changes in ratio of soluble sugars \& free amino nitrogen in the apical meristem during floral transition of tobacco. International Journal of Plant Sciences, 153(1), 78-88.

22. Sharma, A., Bhatnagar, P., Singh, J., Sharma, M. K. \& Jain, M. C. (2016). Growth \& physiological correlation in custard apple cv. Raidurg under consortium of vermicompost \& PSB. HortFlora Research Spectrum, 5(2), 89-98.

23. Sharma, J., Sharma, K. K., Marathe, R. A., Suroshe, S., Babu, K. D. \& Singh, N. V. (2011). Integrated Disease \& Insect Pest Management in Pomegranate. Ext Bull 4, National Research Centre on Pomegranate, Solapur. pp. 129.

24. Sharma, R. (2015). Effect of organic \& inorganic source of nutrients on growth, flowering, fruiting, yield \& quality of mango (Mangifera indica L.) cv. Amrapali under high density planting. In: Ph.D. (Agri.) Thesis, Jawaharlal Nehru Krishi Vishwa Vidyalaya, Jabalpur.

25. Sourabh, Sharma, J. R., Baloda, S., Kumar, R., Sheoran, V., Vijay \& Saini, H. (2018). Response of organic amendments \& biofertilizers on growth \& yield of guava during rainy season. Journal of Pharmacognosy \& Phytochemistry, 7(6), 2692-2695.

26. Thanari, N. \& Suma, R. (2018). Effect of fertigation \& soil application of major nutrients on growth \& yield of pomegranate cv. Bhagwa. International Journal of Chemical Studies, 6(5), 3062-3065.

27. Torshiz, A. O., Goldansaz, S. H., Motesharezadeh, B., Sarcheshmeh, M. A. A. \& Zarei, A. (2017). Effect of organic \& biological fertilizers on pomegranate trees : yield, cracking, sun-burning \& infestation to pomegranate fruit moth Ectomyelois ceratoniae (Lepidoptera : Pyralidae). Journal of Crop Protection, 6(3), 327-340. 